\title{
Jiménez Sardón, D. (2019). Puno en la primera mitad del siglo XX. Indigenismo, Iuchas sociales y obra cultural de Carlos Rubina. Lima: Patronato de la Cultura Altiplánica, Fundación M. J. Bustamante de la Fuente.
}

Aporte para la pintura peruana: luz y paisaje de Carlos Rubina en el Altiplano del siglo XX

Por razones de justicia académica es pertinente señalar, antes de iniciar el comentario del libro Puno en la primera mitad del siglo XX. Indigenismo, luchas sociales y obra cultural de Carlos Rubina (2019) que, en lo que respecta a la autoría del libro solo se ha consignado a uno de los dos autores, tanto en la portada como en la hoja de créditos. Pues, el libro está conformado por dos estudios: el primero: "La época: los movimientos sociales y culturales en el altiplano peruano. Finales del S. XIX - Primeras décadas del XX", del ingeniero agrónomo David Jiménez Sardón, quien aparece como único autor del libro; y, el segundo: "Puno en la obra plástica de Carlos Rubina Burgos (1895-1959)", de la historiadora del arte Sofía Pachas Maceda. De esta manera, se invisibiliza el nombre de la autora en detrimento de su trabajo e investigación. Hecho que debe ser rectificado, en tanto la autora ha hecho pública su legítima protesta.

La primera parte del libro expone a modo de recuento las gestas y movimientos sociales en defensa del indio castrado cultural, educativa y físicamente, que ocurrieron en el altiplano peruano, en el período comprendido entre fines del siglo XIX y las primeras décadas del siglo XX. Ciertamente, Puno fue espacio de confluencia para movimientos culturales y de reivindicación, en los que participaron diversos personajes, especialmente de las élites letradas, que abrazaron la causa indígena tanto en el medio como en otras ciudades, como Lima. En tal sentido, Jiménez Sardón describe, por ejemplo, la labor de la Asociación Pro-indígena, el Comité Pro-Derecho Indígena Tahuantinsuyo, en Lima; y en Puno, las gestas de Juan Bustamante y Santiago Giraldo; las experiencias educativas de Telésforo Catacora, Manuel Z. Camacho y José Antonio Encinas; la lucha de Ezequiel Urviola, entre otros, que persiguen un ideal de justicia y búsqueda de igualdad de derechos. Pero, en tanto aporte, hubiera sido más enriquecedor para el lector, a partir de estos hechos, un análisis que fuera más allá de lo descriptivo y planteara una interpretación del Puno de la época en proyección con los tiempos actuales.

La segunda parte del libro resulta más bien novedosa, en especial para los estudios de la pintura en el Perú, y constituye un aporte para entender la dinámica del arte en el altiplano peruano, a partir de la obra de Carlos Rubina Burgos (1895-1959), pintor, músico y educador, quien desarrolló un trabajo importante en la primera mitad del siglo XX en Puno. Como se sabe, la historia de la pintura en el Perú ha sido estudiada desde la década del cuarenta en la que se pueden rastrear los primeros estudios en torno: La pintura en el Perú (5 años de ambiente artístico) (1942), de Luis Fernández Prada; el artículo de Raúl María Pereira, "Ensayo sobre la pintura peruana contemporánea", en la revista El arquitecto peruano, de junio de 1942; La pintura contemporánea en el Perú (1946), de Juan Ríos; "Las artes plásticas peruanas en el siglo XX", de Juan Manuel Ugarte Eléspuru en La Prensa, en septiembre de 1953, entre otros, que básicamente se han centrado en la producción pictórica hecha en Lima tanto por pintores limeños como por pintores de otras partes del Perú que se afincaron en la capital; por eso, para tener un panorama completo de la pintura peruana, resulta necesario estudiar los diversos aportes pictóricos que se produjeron fuera de la capital.

En el Altiplano, por ejemplo, en la primera mitad del siglo XX se desarrolló un movimiento intelectual, literario, pictórico y musical que, a la par de las vanguardias y de las luchas por la tierra y la defensa del indio, tuvo una presencia importante en el devenir cultural. Conocido es el Grupo Orkopata, dirigido por Gamaliel Churata, en el campo de la literatura, pero menos conocido es el Círculo Pictórico Laykakota, en el campo de la pintura y que, bajo la dirección de un grupo de pintores locales, entre ellos Carlos Rubina Burgos, cimentó en la década del treinta las bases de la pintura puneña a partir de los postulados del indigenismo. Una década antes, Enrique Masías Portugal fue el primero que pintó el paisaje del Altiplano, y Demetrio Peralta Miranda, a fines del veinte, destacó muy joven con sus xilografías en el Boletín Titikaka ${ }^{1}$.

Sofía Pachas Maceda, en este sentido, nos introduce en el imaginario pictórico de Rubina, sobre la base de las fuentes hemerográficas y algunas entrevistas a los familiares. El estudio que, inicialmente, se desarrolla en un tono biográfico, luego presenta un análisis pictórico de la obra del artista, en tanto temática y aspectos formales, y concluye con un apartado al que titula "Legado de Carlos Rubina", donde condensa la labor de Rubina como artista, educador y funcionario, pues fue alcalde de Puno entre 1956 y 1958. Pachas articula en su estudio una narrativa de vida que ensambla el trabajo artístico del personaje, a través de la pintura y la música, con la labor pedagógica y otros quehaceres de tipo social en el contexto cultural de Puno-ciudad entre los años veinte y cincuenta. De esta manera, explora en el ambiente artístico puneño de la época: las exposiciones, las veladas musicales, las actividades con artistas que llegaban de otros ámbitos del Perú, como de Argentina y Bolivia, que le dan un marco pintoresco a la ciudad y que contribuyen a su tradición artística. 
Rubina formaba parte de la clase letrada de la ciudad. Gozaba del prestigio y admiración por la calidad de su trabajo pictórico, pero también porque desde muy joven, desde que era estudiante en el colegio San Carlos, asumió la labor docente en el mismo plantel. El "Perro Rubina" o "Perro Blanco", como lo llamaban, fue un profesor exigente y temido. Sus alumnos hoy lo recuerdan con cariño y destacan su magisterio. Rubina recibió a la vez las enseñanzas de José Antonio Encinas en la emblemática Escuela 881 que este fundó.

En cuanto a la pintura de Rubina, Pachas establece dos grupos temáticos: 1. El lago, la totora, las balsas y viviendas; y 2 . Vida cotidiana en el Altiplano. Observa las características y destaca la particularidad de la luz siempre presente en la pintura de Rubina. Estamos pues ante un pintor esencialmente paisajista, nutrido del encuentro con la naturaleza y el paisaje puneño en el que el lago Titicaca y su dinámica circunlacustre tiene especial presencia. Por eso que, a excepción de un par de cuadros, en los que pinta una de las torres de la Catedral de Puno, como símbolo indiscutible de la ciudad, en su corpus no aparece el Puno citadino de entonces.

A esto hay que sumar el trabajo a carboncillo y a lápiz que Rubina efectuó especialmente en el género del retrato, en el que destaca el "gran acabado", "la depurada técnica del dibujo", el "gusto por el detalle", como refiere Pachas (p. 118), y "la esmerada labor de miniaturista" (p. 119) que Rubina alcanza, por ejemplo, en el retrato que dedica a su madre, en 1919. Vale la pena mencionar este aspecto, puesto que poco se co- noce del Rubina retratista. Asimismo, fue un fiel reproductor de pintores europeos tanto por encargo como aprendizaje.

Con respecto a la proyección de la obra de $\mathrm{Ru}-$ bina esta tuvo como principal lugar de difusión Puno, no obstante que el artista participó tempranamente en una muestra colectiva en Lima, en 1922; pero lo esencial de su trabajo se mostraría en su primera muestra individual en Arequipa, en 1935, y ese mismo año también en Lima, como parte de una exposición con motivo del cuarto centenario de fundación de la capital, en que se pudieron apreciar 140 pinturas puneñas, especialmente de los pintores del Círculo Laykakota. Ello da pie a Pachas para analizar la percepción de la prensa y la crítica en Lima respecto de la pintura periférica. Aparecen entonces las resistencias y articulaciones de la plástica producida en la capital como en las regiones del país. Lo académico y lo autodidacta entra en tensión, discusión que años más tarde tendrá eco en los postulados y defensa de lo universal y lo local, y la abstracción frente al indigenismo, que han sido derroteros interesantes dentro del proceso de la historia de la pintura peruana.

Cabe indicar, finalmente, que el estudio de Sofía Pachas es el primero dedicado a Rubina. Por ello, resulta importante en el panorama de los estudios de la pintura peruana en general y puneña en particular, y es un aporte para seguir ahondando en estos, redescubriendo nuevas imágenes y personajes. En tal sentido, sería oportuno que el estudio de Sofía Pachas se publicara como un libro independiente.

\section{Nota:}

1. Véase Reynoso, Ch. (2019). El arte de Demetrio Peralta: vanguardia y modernidad. Suplemento de la revista Libros \& Artes, 91-92, 1-20.

\section{Christian Reynoso Torres}

Pontificia Universidad Católica del Perú, Lima, Perú

Contacto: christian.reynoso@pucp.pe

https://orcid.org/0000-0002-9949-2476 